\title{
TINJAUAN FIQH SIYASAH DUSTURIYAH TERHADAP UNDANG- UNDANG NOMOR 16 TAHUN 2011 TENTANG BANTUAN HUKUM
}

\author{
Utari Lorensi Putri ${ }^{1}$, Sulastri Caniago² \\ ${ }^{1}$ Institut Agama Islam Negeri Batusagkar \\ e-mail: utarilorensi57@gmail.com \\ 2Institut Agama Islam Negeri Batusangkar \\ e-mail: sulastricaniago@iainbatusangkar.ac.id
}

\begin{abstract}
The focus of the study in this research is on the perspective of fiqh siyasah dusturiyah to the Legislation Number 16 of 2011 concerning Legal Aid. The purpose of this paper is to explain and analyze how the implementation of Legal Aid towards the fulfillment of the rights and justice of the people based on the Indonesian constitution and figh siyasah dusturiyah perspective. Legal Aid itself is so that the rights of the people can be fulfilled in cases in court and out of court. In carrying out Legal Aid must use the principle of justice. Justice is meant to place the rights and obligations of everyone in a proportional, proper, correct, good and orderly manner, the principle of equality in law is that everyone has the same rights and treatment before the law and the obligation to uphold the law. In Islamic courts, the idea of providing legal aid has been formed. The principles of justice and equality before the law or the fulfillment of people's rights are included in the concept of legal aid. The provisions of Islamic law are the most fundamental basis for the existence of Legal Aid in the Islamic legal process.
\end{abstract}

Kata kunci: Legal Aid, Justice, Fulfillment of Rights, and Siyasah Duturiyah

\section{PENDAHULUAN}

Indonesia adalah negara hukum yang termaktub dalam Pasal 1 ayat (2) UndangUndang Dasar 1945 yang memiliki kewajiban untuk melakukan perlindungan dan pengakuan akan hak asasi manusia dari setiap individu atau warga negaranya. Penetapan tersebut diikuti dengan pernyataan bahwa setiap warga negara memiliki kedudukan yang sama di hadapan hukum yang dikenal dengan prinsip equality before the law yang termaktub dalam Pasal 27 ayat (1) Undang-Undang Dasar 1945. Konsekuensi dari prinsip equality before the law, seseorang berhak untuk diperlakukan sama di hadapan hukum, termasuk bagi rakyat miskin yang sedang bermasalah dengan hukum. Berdasarkan hal tersebut terciptalah suatu konsep dan tujuan yang bernama access to law and justice (akses terhadap hukum dan keadilan). Berdasarkan hal tersebut Pemerintah Indonesia mengeluarkan suatu regulasi melalui Undang-Undang Nomor 16 Tahun 2011 tentang Bantuan Hukum. Substansi dari Undang-Undang Bantuan Hukum tersebut menegaskan para penegak hukum untuk memberikan Bantuan Hukum secara cuma-cuma bagi rakyat miskin di Indonesia (Suyogi dan Inge, 2008: 52).

Pemberian Bantuan Hukum haruslah tepat sasaran agar yang benar-benar membutuhkan dapat menerima Bantuan Hukum. Memberikan Bantuan Hukum kepada orang yang membutuhkan adalah perbuatan sangat mulia, karena Allah menyuruh untuk saling tolong menolong sesama manusia. Tentu disini peran Pemerintah sebagai perwakilan dari Allah yang diberikan amanah untuk mewujudkan rasa keadilan serta pemenuhan atas hak-hak rakyat harus dilaksanakan dengan baik. 
Bantuan Hukum merupakan hak dasar negara untuk menjamin warga negara khususnya bagi orang-orang yang kesulitan dalam mendapatkan akses keadilan. Bantuan hukum yang berlaku di Indonesia menganut konsep Legal Aid, dimanapemerintah melalui Kementerian Hukum dan Hak Asasi Manusia memberikan subsidibiaya kepada penerima Bantuan Hukum dalam berperkara secara litigasi di peradilan. Bantuan Hukum menjamin dan memenuhi hak Penerima Bantuan Hukum untuk mendapatkan akses keadilan, mewujudkan hak konstitusional segala warga negara sesuai dengan prinsip persamaan kedudukan di dalam hukum, menjamin kepastian penyelenggaraan Bantuan Hukum dilaksanakan secara merata di seluruh Indonesia. Undang-Undang Bantuan Hukum dalam peradilan memuat jaminan bahwa setiap orang yang tersangkut perkara berhak memperoleh Bantuan Hukum. Ketentuan lain yang diatur adalah pembentukan pos Bantuan Hukum di setiap pengadilan. Sama seperti dalam Undang-Undang No. 48 Tahun 2009, aturan mengenai penanggung jawab pemberian Bantuan Hukum dan pembentukan pos Bantuan Hukum dalam Undang-Undang Peradilan Tata Usaha Negara, UndangUndang Peradilan Umum, dan Undang-Undang Peradilan Agama tidak dijelaskan secara tegas (Chrisbiantoro, dkk, 2014: 13).

Berdasarkan ketentuan Pasal 3 Undang-Undang Bantuan Hukum tujuan dari Bantuan Hukum adalah:

1. Menjamin dan memenuhi hak bagi Penerima Bantuan Hukum untuk mendapatkan akses keadilan;

2. Mewujudkan hak konstitusional segala warga negara sesuai dengan prinsip persamaan kedudukan di dalam hukum;

3. Menjamin kepastian penyelenggaraan Bantuan Hukum dilaksanakan secara meratadi seluruh wilayah Negara Republik Indonesia; dan

4. Mewujudkan peradilan yang efektif, efisien, dan dapat dipertanggung jawabkan.

Berdasarkan Pasal 12 Penerima Bantuan Hukum berhak:

1. Mendapatkan Bantuan Hukum hingga masalah hukumnya selesai dan/atau perkaranya telah mempunyai kekuatan hukum tetap, selama Penerima Bantuan Hukum yang bersangkutan tidak mencabut surat kuasa;

2. Mendapatkan Bantuan Hukum sesuai dengan Standar Bantuan Hukum dan/atau Kode Etik Advokat; dan

3. Mendapatkan informasi dan dokumen yang berkaitan dengan pelaksanaan pemberian Bantuan Hukum sesuai dengan ketentuan peraturan perundang- undangan.

Sebagian para ahli hukum berpendapat bahwa hukum yang bagus adalah hukum yang dapat memenuhi rasa keadilan yang selalu berkembang mengikuti nilai keadilan manusia. Kesadaran hukum masyarakat akan timbul bila ada kesesuaian antara keadilan yang hidup di dalam masyarakat dengan keadilan yang ingin dicapai oleh hukum yang sedang berlaku. Oleh karena itu kepastian hukum hendaknya harus selalu ditegakkan. Antara kepastian dan keadilan merupakan dua sisi yang tidak dapat dipisahkan, karena keduanya saling berkaitan. Dari pernyataan tersebut, timbullah hukum positif yang dapat melindungi masyarakat dan secara tidak langsung akan tercipta hukum yang berdimensi keadilan dan kebenaran. Apabila keadilan dilakukan dengan baik dan bersatu, maka akan terwujud kedamaian, ketentraman dan kebahagiaan dalam kehidupan bermasyarakat (Manan, 2016: 420). 
Semua warga negara berada dalam satu level di hadapan aturan hukum yang berlaku. Tidak terdapat individu atau golongan yang memiliki kesempatan untuk terhindar dari perlakuan aturan (perundang-undangan). Khalifah, gubernur, dan pemegang jabatan lainnya tidak memilki kekebalan hukum, sehingga setiaptindakannya tidak dapat lepas dari hukum dan hukuman. Dalam Al-Quran, Allah memerintahkan agar menegakkan aturan kepada setiap orang yang harus dihukum dan memperlakukan masyarakat secara adil berdasarkan hukum. Asas persamaan di depanhukum merupakan pegangan utama Umar bin Khathab ketika memimpin dunia Islam. Umar tidak pernah membedakan hukuman kepada siapa pun, termasuk kepada anaknya. Setiap individu memiliki hak yang sama untuk mengakses sumber-sumber kekayaan negara. Tidak ada atribut apa pun yang dapat menghalangi individu untuk menikmati sumber-sumber kekayaan. Asas persamaan hak atas kekayaan negara merupakan justifikasi bagi negara dalam mengaplikasikan jaminan sosial. Berdasarkan hal ini, negara secara langsung bertanggung jawab atas penghidupan masyarakat yangmembutuhkan dan tidak memiliki kemampuan untuk mengakses sumber-sumber kekayaan secara sempurna. Kewajiban langsung ini tidak hanya mewajibkan negara untuk memberikan jaminan sosial dalam batas-batas kebutuhan pokok, tetapi mewajibkan negara untuk menjamin kehidupan individu agar sesuai dengan standar hidup layak masyarakat secara umum. Dalam hal ini, jaminan yang diberikan adalah jaminan pemeliharaan (dhaman i'alah), yaitu pemberian bantuan dan sarana kehidupanagar dirinya dapat hidup sesuai standar layak kehidupan masyarakat (Situmorang, 2012: 45).

Setiap warga masyarakat diberi hak dan kebebasan untuk mengeksperesikan pendapatnya. Sepanjang hal itu dilakukan dengan cara yang bijak dan memperhatikanalakhlaq alkarimah dan dalam rangka al-amr bi-'l-ma'ruf wa an-nahy 'an al-'munkar, maka tidak ada alasan bagi penguasa untuk mencegahnya. Bahkan yang harus diwaspadai adalah adanya kemungkinan tidak adanya lagi pihak yang berani melakukan kritik dan kontrol sosial bagi tegaknya keadilan. Jika sudah tidak ada lagi kontrol dalam suatu masyarakat, maka kezaliman akan semakin merajalela.

Kewajiban negara terhadap warga negara dapat dibedakan menjadi dua, yaitu: kewajiban langsung (Immediate Obligations) dan kewajiban progresif (Progresive Obligations). Kewajiban langsung terhadap hak asasi manusia seringkali diwujudkan dalam bentuk proses yuridis, yaitu sementara kewajiban proresif adalah kewajiban yang bisa ditanggalkan apabila kekurangan sumber daya penunjang. Kewajiban negara untuk menghormati hak asasi manusia dan kewajiban melindungi untuk melindungi hak asasi manusia dilihat sebagai kewajiban langsung (Christanugra Philip, 2016: 34). Terdapat juga kewajiban secara hukum yang terkait langsung dengan pemenuhan hak asasi manusia. Kewajiban secara hukum ini diwujudkan dalam dua bentuk, yaitu:

1. Kewajiban untuk meningkatkan yang diwujudkan dalam kebijakan-kebijakan negara, pembentukan institusi-institusi publik demi terpenuhinya hak-hak tersebut.

2. Kewajiban untuk menyediakan seperti penyediaan sumber daya yang dinikmati oleh umum demi terpenuhinya hak-hak asasi manusia.

Negara wajib memenuhi standar tertentu berdasarkan akal dan kebiasaan dalam usahanya memenuhi kewajiban terkait hukum hak asasi manusia. Betapa luasnya kewajiban negara untuk melindungi setiap individu dalam wilayah kekuasaannya. 
Tanggung jawab negara yang dijalankan oleh pemerintah merupakan suatu amanah dari rakyat kepada pemimpin agar dilaksanakan dengan baik. Setiap amanah merupakan kepercayaan yang harus dijaga dan Allah Maha Mengetahui atas apa yang dilakukan setiap manusia (Philip, 2016: 35).

\section{METODE PENELITIAN}

Jenis penelitian ini adalah penelitian kepustakaan (Library Research). Metode yang digunakan adalah hukum normatif. Hukum normatif berupa prilaku hukum. Pokok kajiannya adalah hukum dikonsepkan sebagai norma atau kaidah yang berlaku dalam masyarakat dan menjadi acuan perilaku setiap orang. Sehingga penelitian hukum normatif berfokus pada hukum positif, asas-asas dan doktrin hukum. Teknik pengumpulan data yang penulis gunakan adalah kegiatan mencari dan mencatat data yang dilakukan oleh peneliti untuk menghimpun informasi yang relevan terkait dengan topik atau masalah yang akan atau sedang di teliti. Pengolahan data kualitatif yang dilakukan secara interaktif terus menerus sampai dirasa cukup.

Dengan demikian penelitian ini menggambarkan masalah hukum yang terjadi bagaimana pandangan figh siyasah dusturiyah terhadap Undang-Undang Nomor 16 Tahun 2011 tentang Bantuan Hukum yang berdasarkan pada asas keadilan dan pemenuhan hak kewajiban rakyat. Kemudian penulis akan menganalisanya sehingga diperoleh suatu gambaran yang utuh dan menyeluruh tentang permasalahan yang akan diteliti.

Dalam penelitian ini penulis akan mengkaji Pasal 26, ayat (2) Pasal 27, Pasal 29 ayat (2) dan Undang-Undang Dasar Negara Republik Indonesia Tahun 1945, Pasal 9, Pasal 10 Pasal 13 Undang-Undang Nomor 16 Tahun 2011 tentang Bantuan Hukum. Adapun penelitian yang penulis lakukan yaitu mencari bahan untuk mendapatkan literatur yang berhubungan dengan penelitian penulis.

\section{HASIL DAN PEMBAHASAN}

Warga negara secara umum dinyatakan bahwa merupakan anggota dari negara yang mempunyai kedudukan khusus terhadap negaranya. Ia mempunyai hak dan kewajiban yang bersifat timbal balik terhadap negaranya sehingga sebagai warga negara yang baik, seseorang akan terlebih dahulu mendahulukan kewajibannya sebagai warga negara dari pada meminta haknya terlebih dahulu. Berdasarkan hal tersebut maka hak dan kewajiban warga negara terhadap negaranya sebagai sebuah keseimbangan (Kurdi, 2000: 114).

Pemberian Bantuan Hukum merupakan sarana prasarana penunjang bagi penegakan hukum pada umumnya dan usaha perlindungan hak-hak asasi manusia dari tindakan sewenang-wenang aparat penegak hukum. Hak-hak warga negara tidak ada artinya bilamana secara sewenang-wenang negara dapat membunuh, menangkap, menahan, menyiksa, menggeledah, dan menyita barang seorang warga negara dengan sewenang-wenang. Praktik tersebut menyimpang dari ketentuan suatu negara hukum (Rukmini, 2007: 111). 
Pemberian Bantuan Hukum merupakan kewajiban negara dan negara yang menentukan syarat-syarat bagi Penerima Bantuan Hukum. Cara negara dalam memberikan Bantuan Hukum adalah dengan menyediakan dana kepada Pemberi Bantuan Hukum. Advokat yang memberikan Bantuan Hukum merupakan pelaksanaan Bantuan Hukum oleh negara yang diatur dalam Undang-Undang Bantuan Hukum. Pemberian Bantuan Hukum oleh negara terdapat dalam falsafahHAM di Indonesia yaitu Undang-Undang Dasar 1945 yang menjamin tegaknya negara hukum Indonesia sebagaimana diisyaratkan dalam penjelasan dan dalam Batang Tubuh Undang-Undang Dasar 1945. Kemudian apabila dihubungkan dengan teori atau paham negara hukum, tampaknya Undang-Undang Dasar 1945 menjamin pula bahwa Indonesia bukan sekedar negara hukum dalam artian formal atau sempit, melainkan negara hukum dalam arti material atau dalam arti luas. Kesimpulan ini dipertegas dalam alinea ke-4 Pembukaan Undang-Undang Dasar 1945 yang berbunyi:

"Kemudian daripada itu untuk membentuk suatu Pemerintahan Negara Indonesia yang melindungi segenap bangsa Indonesia dan seluruh tumpah darahIndonesia dan untuk memajukan kesejahteraan umum, mencerdaskan kehidupan bangsa dan ikut melaksanakan ketertiban dunia yang berdasarkan kepada kemerdekaan, perdamaian abadi dan keadilan sosial..."(Rukmini, 2007: 50-51).

Berdasarkan ketentuan Pasal 2 Undang-Undang Bantuan Hukum Penerima Bantuan Hukum adalah orang atau kelompok orang miskin. Konsekuensi dari prinsip persamaan dihadapan hukum menyatakan bahwa orang miskin berhak untuk disamakan di hadapan hukum ketika ada perkara di pengadilan. Terlebih laginegara Indonesia secara konstitusi pada Pasal 34 (1) Undang-Undang Dasar 1945 menyatakan bahwa fakir miskin dan anak terlantar dipelihara oleh negara. Frasa dipelihara bukan sekedar memberikan kebutuhan akan pangan dan sandang saja, akan tetapi kebutuhan akan akses hukum dan keadilan dengan kata lain prinsip equality before the law tidak hanya memaknai sebagai persamaan di mata hukum saja (Suyogi dan Inge, 2018: 3).

Berdasarkan ketentuan Pasal 3 Undang-Undang Bantuan Hukum tujuan dari Bantuan Hukum adalah :

1. Menjamin dan memenuhi hak bagi Penerima Bantuan Hukum untuk mendapatkan akses keadilan;

2. Mewujudkan hak konstitusional segala warga negara sesuai dengan prinsip persamaan kedudukan di dalam hukum;

3. Menjamin kepastian penyelenggaraan Bantuan Hukum dilaksanakan secaramerata di seluruh wilayah Negara Republik Indonesia; dan

4. Mewujudkan peradilan yang efektif, efisien, dan dapat dipertanggungjawabkan.

Berdasarkan Pasal 12 Penerima Bantuan Hukum berhak:

1. Mendapatkan Bantuan Hukum hingga masalah hukumnya selesai dan/atau perkaranya telah mempunyai kekuatan hukum tetap, selama Penerima BantuanHukum yang bersangkutan tidak mencabut surat kuasa;

2. Mendapatkan Bantuan Hukum sesuai dengan Standar Bantuan Hukum dan/atau Kode Etik Advokat; dan

3. Mendapatkan informasi dan dokumen yang berkaitan dengan pelaksanaan pemberian Bantuan Hukum sesuai dengan ketentuan peraturan perundang- undangan. 
Berdasarkan Pasal 3 dan Pasal 12 Undang-Undang Bantuan Hukum diatas, tampak bahwa pemberian Bantuan Hukum merupakan suatu kewajiban negara yang harus dilaksanakan agar semua hak-hak warga negara dalam berperkara dapat terpenuhi dan terlaksanakan. Dalam hal ini Undang-Undang Bantuan Hukum Nomor 16 Tahun 2011 sangat melindungi hak-hak Penerima Bantuan Hukum dalam mendapatkan Bantuan Hukum dari awal perkara sampai dengan selesai, tentu Lembaga Bantuan Hukum sebagai salah satu bentuk lembaga pemberian Bantuan Hukum yang menjalankan peraturan Undang-Undang Bantuan Hukum sejalan dengan siyasah dusturiyah yang membahas peraturan perundang-undangan negara oleh hal ihwal yang mana peraturan tersebut demi kemaslahatan warga negara agar tercapainya prinsip pemenuhan hak-hak warga negara. Karena memberikan Bantuan Hukum merupakan salah satu perwujudan dari terpenuhinya hak-hak setiap warga negara.

Bantuan Hukum secara individu dan pembela umum yang bekerja untuk organisasi Bantuan Hukum, karena sesungguhnya Bantuan Hukum adalah profesi advokat pembelaan oleh advokat atau pembela umum akan lebih menjamin tidak terjadinya insiden penyiksaan, perlakuan tidak manusiawi, merendahkan martabat manusia, dan hukuman kejam lainnya. Bantuan Hukum memang diperlukan oleh masyarakat Indonesia yang menginginkan pembelaan secara menyeluruh dengan tidak membedakan oembelaan untuk bidang hukum tertentu saja atau hak asasi manusia. (Frans, 2009: 18).

Berdasarkan Pasal 2 Undang-Undang Bantuan Hukum, Bantuan Hukum diselenggarakan berdasarkan asas :

1. Keadilan;

2. Persamaan kedudukan di dalam hukum;

3. Keterbukaan;

4. Efisiensi;

5. Efektivitas; dan

6. Akuntabilitas.

Berdasarkan asas-asas Bantuan Hukum diatas keadilan yang dimaksud adalah menempatkan hak dan kewajiban setiap orang secara proporsional, patut, benar, baik, dan tertib, asas persamaan kedudukan di dalam hukum adalah bahwa setiap orang mempunyai hak dan perlakuan yang sama di depan hukum serta kewajiban menjunjung tinggi hukum, asas keterbukaan" adalah memberikan akses kepada masyarakat untuk memperoleh informasi secara lengkap, benar, jujur, dan tidak memihak dalam mendapatkan jaminan keadilan atas dasar hak secara konstitusional, asas efisiensi" adalah memaksimalkan pemberian Bantuan Hukummelalui penggunaan sumber anggaran yang ada, asas efektivitas" adalah menentukan pencapaian tujuan pemberian Bantuan Hukum secara tepat, dan asas akuntabilitas" adalah bahwa setiap kegiatan dan hasil akhir dari kegiatan penyelenggaraan Bantuan Hukum harus dapat dipertanggungjawabkan kepada masyarakat.

Akses terhadap keadilan diartikan sebagai kemampuan masyarakat untuk memperoleh keadilan yang sesuai dengan stndar hak asasi manusia. Hak ini merupakan akses bagi masyarakat, khususnya kelompok miskin terhadap mekanisme yang adil, efektif dan akuntabel untuk melindungi hak, menghindari penyalahgunaan adalah kemampuan masyarakat untuk memperoleh penyelesaian melalui formal dan informal 
dalam sistem hukum, serta kemampuan untuk memperoleh dan terlibat dalam proses pembuatan, penerapan, dan pelembagaan hukum (Suyogi dan Inge, 2018: 8).

Hak untuk memperoleh Bantuan Hukum merupakan hak dasar atau asasi bagi seseorang yang terkena masalah hukum. Sebab memperoleh Bantuan Hukummerupakan salah satu bentuk akses terhadap keadilan bagi mereka yang bermasalah hukum. Memperoleh Bantuan Hukum juga salah satu perwujudan dari persamaan di depan hukum. Prinsip equality before the law sudah dimuat dalam Pasal 28 D ayat (1) UndangUndang Dasar 1945, yaitu setiap orang berhak atas pengakuan, jaminan, perlindungan, dan kepastian hukum yang adil serta perlakuanyang sama di hadapan hukum (Asfinawati dan Santosa, 2007: 97).

Melalui Bantuan Hukum diharapkan fakir miskin dapat memperoleh keadilan sosial. Untuk mewujudkannya maka perlu perubahan pada konsep Bantuan Hukum. Konsep Bantuan Hukum yang dapat mendorong terwujudnya keadilan sosial adalah konsep Bantuan Hukum responsif. Dengan Bantuan Hukum responsif, fakir miskin menerima Bantuan Hukum secara cuma-cuma dan menyeluruh meliputi semua bidang hukum dan hak asasi manusia, tanpa memprioritaskan bidang hukum dan hak asasi manusia tertentu, tanpa membedakan. Mengingat masyarakat Indonesia yang pluralistik, maka konsep Bantuan Hukum responsif adalah sesuai dengan budaya, aspirasi, dan rasa adil yanghidup di dalam masyarakat yang beragam tersebut. Bantuan Hukum responsif ini dapat dilakukan dalam bentuk penyuluhan hukum tentang hak asasi manusia dan proses hukum, hak untuk dibela oleh Bantuan Hukum dan/atau advokat pembelaan dalam mengatasi masalah-masalah hukum yang konkret, pembelaan di dalam pengadilan yang berkualitas agar menghasilkan yurisprudensi yang lebih tegas, tepat, jelas, dan benar, serta mendukung pembaharuan hukum melalui putusan pengadilan yang berpihak kepada kebenaran dan pembetukan Undang-Undang yangs sesuai dengan sistem nilai dan budaya yang ada dalam masyarakat (Frans, 2009: 33).

\section{Fiqh Siyasah Dusturiyah}

Dalam peradilan Islam telah terbentuk pemikiran pemberian Bantuan Hukum. Pemberian Bantuan Hukum diberikan kepada pencari keadilan tanpa pembiayaan. Prinsip keadilan dan persamaan dihadapan hukum atau pemenuhan hak-hak rakyat termasuk di dalam konsep Bantuan Hukum. Nabi Muhammad SAW selain menjadi seorang Rasul, juga berperan dalam memberikan Bantuan jasa hukum pada umatnya. Bahkan bertindak sebagai advokat, konsultan hukum, penasihat hukum, dan arbiter (Salda, 2020: 182)

Pada konsep hukum Islam, manusia berkedudukan sama dihadapan hukum. Pemenuhan hak dan kewajiban merupakan tujuan dari keadilan hukum itu sendiri. Otoritas pembuat hukum mutlak berada di tangan Allah sedangkan penguasa dan rakyat hanya diberi amanat untuk menyelesaikan urusan-urusan publik bersumber pada wahyu dan selebihnya ditentukan oleh manusia melalui ijtihad berdasarkan prinsip musyawarah (Khaliq, 2005: 29).

Mengenai hak-hak rakyat, menurut Abu-al-A'la al-Maududi meliputi perlindungan terhadap hidupnya, hartanya, dan kehormatannya, perlindungan terhadap kebebasan pribadi, kebebasan menyatakan pendapat dan berkeyakinan, dan terjaminnya kebutuhan pokok hidupnya dengan tidak membedakan kelas dankepercayaan. Akibat hak-hak yang 
diterima oleh rakyat, maka warga mempunyai tugas tertentu atas hak-hak negara. Tugas warga negara yang harus dan wajib ditunaikan menurut Abu al-A'la al- Maududi adalah patuh dan taat kepada pemerintah dalam batas yang tidak bertentangan dengan agama, setia kepada negara, rela berkorban untuk membela negara dari bermacam ancaman dan bersedia memenuhi kewajiban materiil yang dibebankan padanya oleh negara. Demikian kewajiban rakyat dan menyerahkan pelaksanaannya pada negara untuk menjamin keseimbangan antara dua pihak, yakni rakyat dan negara agar masing- masing hak tidak terlanggar atau mendominasi pihak lainnya.

Pada konsep Hukum Islam, manusia berkedudukan sama di depan hukum dan berhak mendapatkan jaminan keadilan. Dari konsep tersebut, pemenuhan hak dan kewajiban hukum menjadi tujuan keadilan hukum itu sendiri untuk menjaminpersamaan hukum dan keadilan. Pada dasarnya, konsep Bantuan Hukum (the concept of legal aid) atau (legal service) berkaitan erat dengan hukum Islam yang megajarkan kepada pemeluknya agar melindungi hak-hak hukum setiap individu dimana setiap orang sama kedudukannya didepan hukum, dan adanya suatu kewajiban menegakkan hukum dan keadilan bagi setiap individu. Ketentuanhukum Islam tersebut menjadi dasar yang paling fundamental bagi adanya Bantuan Hukum dalam proses hukum Islam. Konsep Bantuan Hukum berkaitan erat dengan ketentuan hukum Islam, bahwa setiap orang sama kedudukannya di depan hukum dan adanya suatu kewajiban menegakkan hukum dan keadilan bagi setiap individu. Bantuan hukum sebagai salah satu perwujudan dari tercapainya peradilan yang adil dan tidak memihak.

Setiap orang berhak untuk memperoleh keadilan dengan mengajukan permohonan, pengaduan, dan gugatan baik perkara pidana maupun perdata. Berdasarkan salah satu asas dalam Bantuan Hukum adalah keadilan. Di dalam memberikan Bantuan Hukum kepada Penerima Bantuan Hukum hal pertama yangharus terpenuhi adalah keadilan. Hak untuk mendapatkan Bantuan Hukum, sebenarnya hanya merupakan salah satu dari akses terhadap keadilan. Konsep atasakses terhadap keadilan tidak hanya berarti akses terhadap advokat atau pengadilan, namun juga berarti akses terhadap Ombudsman dan lembagalembaga keadilan yang lain. Adil merupakan salah satu nilai-nilai yang terdapat dalam Pancasila. Adil yang dimaksudkan adalah adil terhadap diri sendiri, adil terhadap sesama manusia, dan adil terhadap Tuhan. Dengan dilandasi oleh sila kemanusiaanyang adil dan beradab tersebut, maka keadilan hukum yang dimiliki bangsa Indonesia adalah keadilan yang memanusiakan manusia (Prasetyo, 2015: 109).

Syekh Musthafa Al-Maraghy dalam tafsirnya menjelaskan akan kewajiban menjaga kesatuan umat manusia (wahdatul basyar), menjaga kelangsungan hidup mereka, menyingkirkan segala hal yang dapat membahayakan setiap individu danmemenuhi hak setiap individu. Jika melanggar dan merusak kehormatan individuitu berararti merusak kehormatan seluruh manusia, sebaliknya ketika memenuhi hak-hak individu maka telah memenuhi hak-hak seluruh manusia (Al-Maraghy, 1946: 102).

Perlindungan terhadap Hak Asasi Manusia (HAM) telah lama dikenal dalam Islam. Perlindungan Hak Asasi Manusia (HAM) ini merupakan salah satu bentuk upaya mencapai keadilan. Jika ditelaah lagi banyak ayat dalam Al-Qur'an dan As-Sunnah menjadi dasar adanya hak untuk hidup. Disini harus ada pemenuhan semua hak-hak sebagai manusia yang tinggal di suatu negara 
Prinsip-prinsip siyasah dusturiyah yang berkaitan dengan konsep Bantuan Hukum adalah asas persamaan dan keadilan. Asas Persamaan (Mabda Al-Musawah) memiliki arti bahwa setiap individu memiliki derajat yang sama sebagai warga negara tanpa mempertimbangkan asal-usul, ras, agama,bahasa, dan status sosial. Semua oang memiliki kesamaan dalam hal menuntut dan dituntut, yaitu menuntut hak dan dituntut melaksanakan kewajiban. Persamaan dalam doktrin ketatanegaraan Islam adalah persamaan konstitusional (qanuniyyah), bukan persamaan factual (fa'liyyah). Artinya, persamaan yang diajarkan oleh Islam adalah semua orang harus dijamin setara oleh undang-undang, walaupun dalam kenyataan faktual mereka memliki perbedaan, baik secara fisik, kapasitas intelektual, dan kekayaan. Doktrin persamaan ketatanegaraan ini berbeda dengan doktrin persamaan dalam kesamaan konstitusional. Asas persamaan Islam menganut doktrin persamaan proposional yang terdapat dalam ajaran: bagi setiap orang sesuai dengan usahanya dan tingkat kebutuhannya. Asas persamaan (mabda almusawarah) merupakan bawaan Islam yang berbeda dengan asasmasyarakat sebelumnya. Ia merupakan implementasikan dari keyakinan bahwa Tuhan itu hanya satu, yaitu Allah. Seluruh makhluk setara di hadapan-Nya, mereka sama-sama memiliki hak dan kewajiban tanpa dibedakan ras, warna kulit, kebangsaan, dan kekayaan.

Subhi Mahsami dikenal sebagai salah seorang pemikir islam dari Mesir yang dalam bukunya Huquq Al-Insan Fi Al-Islam. Menurutnya konsep Hak AsasiManusia dalam Islam disetarakan hak dan kewajiban antara sesama manusia. Konsep ini berpijak secara normatif pada prinsip persamaan dan kebebasan dalamnorma-norma syari'ah bahwa asas paling fundametal tentang harkat dan martabat kemanusiaan lebih didasarkan pada pemenuhan hak dan kewajiban yang melekat pada setiap manusia tanpa diskriminasi ras, suku, warna kulit, bahasa, jeniskelamin, keyakinan agama, sikap politik, dan status sosial. Persamaan hak ini dasar bagi perumusan konsep Bantuan Hukum dalam hukum Islam. Disini tampak jelas bahwa ajaran Islam sangat menjunjung harga diri manusia dalam mencapai hak- haknya sebagai warga negara dalam suatu negara. Di dalam siyasah dusturiyah yang membahas pengaturan perundang-undangan oleh hal ihwal kenegaraan yang bertujuan untuk memenuhi kebutuhan-kebutuhan warga negaranya yang sesuai dengan prinsip-prinsip dalam ajaran Islam agar terciptanya pemenuhan hak-hak warga negara. Dalam mencapai hal tersebut Indonesia telah mengeluarkan peraturan yaitu Undang-Undang Bantuan Hukum Nomor 16 Tahun 2011. Di dalam peraturan tersebut telah diatur sedemikian rupa mengenai hak-hak warga negara dalam mendapatkan Bantuan Hukum dan kewajiban warga negara dalam Bantuan Hukum (Kusnadi, 2012: 38).

Siyasah dusturiyah mempelajari hubungan antara pemimpin pada satu pihak dan rakyat pada pihak lain, serta kelembagaan yang terdapat dalam masyarakat. Pembahasan utama dari siyasah dusturiyah meliputi hal-hal di bawahini:

1. Kajian tentang konsep imamah, khilafah, imarah, mamlakah, berikut hak dan kewajibannya;

2. Kajian tentang rakyat, kedudukan, hak, dan kewajibannya;

3. Kajian tentang bai'ah dari zaman ke zaman;

4. Kajian tentang Waliyul Ahdi;

5. Kajian tentang perwakilan atau wakalah;

6. Kajian tentang ahl al-halli wa al-aqd; 
7. Kajian tentang wuzarah, sistem pemerintahan presidential dan parlementer;

8. Kajian tentang pemelihan umum.

Dalam siyasah dusturiyah dikaji secara mendalam hal-hal yang berhubungan dengan perwakilan rakyat, hubungan orang muslim dengan nonmuslim dalam suatu pemerintahan dan negara, partai politik, pemeliharaan umum, dan sistem pemerintahan yang dianut suatu negara tertentu. Bidang yang berkaitan dengan hal ini disebut dengan siyasah tasri'iysh. Persoalan kepemimpinan dalam suatu negara berkaitan pula dengan adanya janji-janji pemimpin pada umumnya yang diikrarkan secara sakral, sebagaimana dikatakan sebagai bai'ah. Sedangkan sistem pemerintahan dan kabinet seta waliyul ahdi disebut sebagai siyasah tanfidiyah.

Sumber figh dusturi pertama adalah Al-Qur'an al -Karim yaitu ayat-ayat yang berhubungan dengan prinsip-prinsip kehidupan kemasyarakatan, dalil-dalil kulliy dan semangat ajaran Al-Qur'an. Kemudia kedua adalah hadis-hadis yang berhubunganmdengan imamah, dan kebijaksanaan Rasulullah SAW di dalammenerapkan hukum di negeri Arab. Ketiga adalah kebijakan-kebijakan khulafaur rasyidin di dalam mengendalikan pemerintahan. Meskipun mereka mempunyai perbedaaan dalam gaya pemerintahannya sesuai dengan pembawaan masing-masing, tetapi ada kesamaan alur kebijakan yaitu, berorientasi kepada sebesar- besarnya kepada kemaslahatan rakyat. Keempat adalah hasil ijtihad para ulama, didalam masalah figh dusturi hasil ijtihad ulama sangat membantu dalam memahami semangat dan prinsip figh dusturi. Dalam mencapai kemaslahatan umat misalnya haruslah terjamin dan terpelihara dengan baik. Dan sumber yang kelima adalah adat kebiasaan suatu bangsa yang tidak bertentangan dengan prinsipprinsip Al- Qur'an dan hadist. Adat kebiasaan semcam ini tidak tertulis yang sering diistilahkan dengan konvensi (Djazuli, 2004: 53-54).

\section{KESIMPULAN}

Berdasarkan dua rumusan masalah yang telah penulis teliti dapat disimpulkan bahwa untuk rumusan masalah pertama bentuk pemenuhan hak dan keadilan bagi warga negara dalam Undang-Undang Nomor 16 Tahun 2011 tentang Bantuan Hukum menurut Konstitusi Negara Indonesia telah terjawab. Dalam bentuk pemenuhan hak dan keadilan bagi warga negara sudah diatur sedemikian rupa jelasnya dalam Undang-Undang Bantuan Hukum dan peraturan perundang- undangan yang terkait dalam aturan pemenuhan hak dan keadilan bagi rakyat. Untuk rumusan masalah kedua pemenuhan hak dan keadilan bagi warga negara menurut Undang-Undang Nomor 16 Tahun 2011 tentang Bantuan Hukum perspektif figh siyasah dusturiyahtelah terjawab. Dalam hukum Islam pelaksanaandari Bantuan Hukum merupakan salah satu bentuk dari prinsip-prinsip siyasah dusturiyah. Adanya prinsip untuk saling tolong menolong sesama manusia dan memberikan hak kepada yang berhak menerimanya dengan asas keadilan. Dari penjelasan tersebut, dua rumusan masalah yang penulis teliti sudah terjawab permasalahannya. 


\section{DAFTAR PUSTAKA}

Al-Maraghy, M. (1946) Tafsir Al-Maraghy. Kairo. Babil Halaby.

Asfinawati dan Mas A. S. (2007). Bantuan Hukum Akses Masyarakat Marjinal Terhadap Keadilan Tinjauan Sejarah, Konsep, Penerapan, Dan Perbandingan Diberbagai Negara. Jakarta: LBH Jakarta.

Chrisbiantoro, dkk. (2014). Bantuan Hukum Masih Sulit Diakses. Jakarta Pusat: KomisiUntuk Orang Hilang dan Tindak Kekerasan (kontras).

Fauzi, S.I \& Ningtyas, I.P. (2018) Optimalisasi Pemberian Bantuan Hukum Demi Terwujudnya Access To Justice To Law And Justice Bagi Masyarakat Rakyat Miskin. Jurnal Fakultas Hukum Universitas Jendral Soedirman.

Johan. (2009) Hak Asasi Manusia Dan Hak Serta Kewajiban Warga Negara Syiar Hukum Dalam Hukum Positif Indonesia. 11 (2).

Kansil, C.S.T, \& Christine. S.T. Kansil. (2000) Hukum Tata Negara. Jakarta: Rineka Cipta. Djazuli. 2007. Kaidah-Kaidah Fikih Islam Dalam Menyelesaikan Masalah-Masalah yang Praktis. Jakarta. Kencana.

Khaliq, F.A. (2005) Fiqh Politik Islam. Jakarta (t.t)

Kurdi, dkk. (2000) Tatanan Sosial Islam Studi Berdasarkan Al-Qur'an dan Sunnah. Yogyakarta. Pustaka Pelajar. Cet Ke-1.

Kusnadi, D. (2012) Bantuan Hukum Dalam Islam. Bandung : CV. Pustaka Setia.

Manan. A. (2016) Hukum Ekonomi Syariah Dalam Perspektif Kewenangan Peradilan Agama. Jakarta. Kencana.

Philip, C. (2016) Tanggung Jawab Negara Terhadap Perlindungan Hak Asasi Manusia Menurut Hukum Internasional. Lex Administratum, 4 (2).

Prasetyo, T. (2015) Keadilan Bermartabat Perspektif Teori Hukum. Jakarta: Nusa Media.

Rukmini, M. (2007) Perlindungan Hak Asas Manusia Asas Praduga Tak Bersalah Dan Asas Persamaan Kedudukan Dalam Hukum Pada Sistem Peradilan Pidana Indonesia. Bandung. Alumni.

Salda, M. (2020) Hak Bantuan Hukum Prodeo Dalam Hukum Islam dan Hukum Nasional. Kanun Jurnal Ilmu Hukum, 22 (1): 182.

Winarta, F. H. (2009) Pro Bono Publico Hak Konstitusional Fakir Miskin Untuk Memperoleh Bantuan Hukum. Jakarta. PT Gramedia Pustaka Utama.

Winarta, F. H. (2009) Suara Rakyat Hukum Tertinggi. Jakarta. PT Kompas Media Nusantara. 